\title{
Jurnal
}

Manajemen Kesehatan Indonesia

\section{EVALUASI PENERIMAAN SISTEM INFORMASI PELAYANAN KESEHATAN IBU DENGAN METODE TAM DI DINAS KESEHATAN KABUPATEN BUNGO}

\author{
Martunus $^{*}$, Farid Agushybana**, Sri Achadi Nugraheni** \\ *Dinas Kesehatan Kabupaten Muara Bungo \\ **Staf Pengajar Program Magister Ilmu Kesehatan Masyarakat Universitas Diponegoro \\ Email: tunusfakhri@yahoo.com
}

\begin{abstract}
Based on the results of the preliminary study, it was found that collecting maternal health data at the Bungo District health office often experienced collection delays, incomplete data filling and required a long time to present the required data. The purpose of this study was to implement an evaluation of the acceptance of the maternal health service information system using the TAM method in the Bungo District health office.
\end{abstract}

The was observational analytics study, using multiple linear regression analysis to determine the relationship between the variables of perception of ease, perception of benefits with variable attitudes and interests to use the maternal health information system. The research subjects were village midwives and coordinating midwives in 19 health centers with 38 people.

The perception variables on ease affect the attitude to use SIK with the value of $P$-Value $=0,000$. The perception variables on ease influence the interest to use SIK with the value of P-Value $=0.002$. The perception variable on expediency influences the attitude to use SIK with the value of $P$-Value $=0.003$. The perception variable on expediency influences the interest to use SIK with the value of P-Value $=0.002$. The need for ongoing training related to the Maternal Health Information System so that it can improve skills and increase the confidence of midwives in using the Maternal Health Service Information System.

Keywords: Evaluation of System Information, TAM, Behavioural Intention to Use

\section{PENDAHULUAN}

Evaluasi program kesehatan ibu merupakan salah satu dari evaluasi program yang ada guna untuk memantau perkembangan pelayanan kesehatan ibu di tempat pelayanan. Evaluasi hasil pelaksanaan program kesehatan ibu dan anak dilaksanakan berdasarkan dengan laporan bulanan KIA, kelahiran dan kematian per kecamatan, penemuan kasus BBLR per kecamatan, penemuan kasus tetanus neonatorium per kecamatan, 
kematian ibu, registrasi kematian perinatal (0-7 hari), pemantauan wilayah setempat indikator ibu, pemantuan wilayah setempat indikator anak dan laporan bulanan standard pelayanan minimal (SPM) kesehatan ibu dan anak. ${ }^{1}$

Berdasarkan hasil studi pendahuluan didapatkan bahwa pengumpulan data kesehatan ibu pada dinas kesehatan Kabupaten Bungo sering mengalami keterlambatan pengumpulan, kurang lengkapnya pengisian data dan membutuhkan waktu yang lama untuk menyajikan data yang diperlukan untuk pengambilan keputusan secara cepat dan tepat. Untuk mengatasi permasalahan tersebut, dilakukan penerapan Sistem Informasi Kesehatan Ibu di Dinas Kesehatan Kabupaten Bungo. Namun, analisis penerimaan bidan terhadap sistem informasi kesehatan ibu akan sangat diperlukan agar penerapan Sistem Informasi Kesehatan Ibu dapat berjalan secara optimal.

Salah satu model evaluasi yang dapat digunakan untuk menilai penerimaan dan penggunaan sebuah sistem teknologi informasi adalah evaluasi dengan menggunakan metode model penerimaan teknologi (Technology Acceptance Model atau TAM). Model TAM digunakan untuk menganalisis dan memahami faktor-faktor yang mempengaruhi diterimanya penggunaan teknologi informasi. ${ }^{2}$

Salah satu faktor yang dapat mempengaruhi sikap dalam penerimaan teknologi adalah persepsi pengguna terhadap kemanfaatan dan kemudahan pengguna teknologi informasi sebagai suatu tindakan beralasan sehingga alasan seorang dalam melihat manfaat dan kemudahan penggunaan teknologi informasi menjadikan tindakan/perilaku orang tersebut sebagai tolak ukur dalam penerimaan sebuah teknologi.Penerimaan individu terhadap sistem teknologi informasi ditentukan oleh 5 aspek yang perlu ditanyakan yaitu : persepsi pengguna terhadap kemudahan, persepsi pengguna terhadap kemanfaatan, sikap terhadap penggunaan, niat untuk menggunakan dan kondisi nyata penggunaan. 3

Berdasarkan latar belakang tersebut peneliti tertarik untuk melakukan evaluasi penerapan Sistem Informasi Kesehatan Ibu pada bidan dengan metode TAM yang akan ditinjau melalui empat aspek yaitu persepsi pengguna terhadap kemudahan, persepsi pengguna terhadap kemanfaatan, sikap terhadap penggunaan dan niat untuk menggunakan yang akan dilakukan di wilayah kerja Dinas Kesehatan Kabupaten Bungo.

\section{METODE PENELITIAN}

Penelitian ini menggunakan model penelitian observasional analitik yaitu mencari hubungan antar variabel dengan melakukan suatu analisis terhadap data yang dikumpulkan. Penelitian dilakukan pada bulan Februari 2018 - Februari 2019. Pengumpulan data menggunakan kuesioner (self-administered questionnaire). Sampel penelitian ini yaitu bidan petugas poliklinik kesehatan ibu anak dan bidan koordinator di 19 puskesmas sejumlah 38 orang. Analisis data yang digunakan menggunakan Analisis Regresi Linear Berganda.

\section{HASIL DAN PEMBAHASAN}

Responden penelitian ini berjumlah 38 orang yang terdiri atas bidan pada poliklinik kesehatan ibu anak dan bidan koordinator disetiap puskesmas pada Dinas Kesehatan Kabupaten Bungo. Karakteristik dalam penelitian meliputi tingkat pendidikan (D3 yaitu 36 orang $(94,73 \%)$ sedangkan untuk pendidikan D4 yaitu 2 orang $(5,27 \%)$, usia (26-30 tahun sebanyak 12 orang $(23,7 \%)$ dan paling sedikit pada usia 21-25 tahun dan 45-50 tahun sebanyak 2 orang (5,26\%). Masa Kerja 6-10 tahun sebanyak 12 orang $(31,25 \%)$ 
Tabel 1. Distribusi Jawaban Responden Terhadap Variabel

\begin{tabular}{|c|c|c|c|}
\hline Pernyataan & Setuju & $\begin{array}{l}\text { Sangat } \\
\text { Setuju }\end{array}$ & Indeks/Kriteria \\
\hline \multicolumn{4}{|l|}{ Persepsi terhadap Kemudahan } \\
\hline a. Tidak mengalami kesulitan terhadap penggunaan & 7 & 31 & 36,6/Tinggi \\
\hline b. Menu yang ada mudah dipahami dan digunakan & 12 & 26 & 35,6/Tinggi \\
\hline c. Form data ibu hamil mudah dipahami pengisiannya & 8 & 30 & $36,4 /$ Tinggi \\
\hline d. Proses pemasukan data mudah dan cepat & 13 & 25 & $35,4 /$ Tinggi \\
\hline e. Proses pemasukan data mudah dan cepat & 21 & 17 & 33,8/Tinggi \\
\hline f. SIK ibu mudah diakses dimanapun & 6 & 32 & 36,8/Tinggi \\
\hline \multicolumn{4}{|l|}{ Persepsi terhadap Kemanfaatan } \\
\hline $\begin{array}{l}\text { a. Laporan SIK digunakan untuk pemantauan dan } \\
\text { pendampingan ibu hamil }\end{array}$ & 15 & 23 & 35/Tinggi \\
\hline b. Penggunaan SIK meningkatkan kinerja & 20 & 17 & 33,6/Tinggi \\
\hline $\begin{array}{l}\text { c. Penggunaan SIK mempermudah pencatatan dan } \\
\text { pelaporan }\end{array}$ & 11 & 27 & 35,8/Tinggi \\
\hline $\begin{array}{l}\text { d. Penggunaan SIK mempercepat pencatatan dan } \\
\text { pelaporan }\end{array}$ & 14 & 24 & 35,2/Tinggi \\
\hline $\begin{array}{l}\text { e. Penggunaan SIK meningkatkan keterampilan } \\
\text { pencatatan dan pelaporan }\end{array}$ & 9 & 29 & 36,2/Tinggi \\
\hline \multicolumn{4}{|l|}{ Sikap untuk Menggunakan SIK } \\
\hline $\begin{array}{l}\text { a. Saya mendukung pencatatan dan pelaporan dengan } \\
\text { SIK }\end{array}$ & 11 & 27 & 35,8/Tinggi \\
\hline b. Dengan SIK penginputan data dapat lebih cepat & 15 & 23 & 35/Tinggi \\
\hline c. Data ibu hamil tersedia dengan lengkap pada SIK & 18 & 20 & 34,4/Tinggi \\
\hline $\begin{array}{l}\text { d. Pencatatan dan pelaporan lebih baik menggunakan } \\
\text { SIK }\end{array}$ & 11 & 27 & 35,8/Tinggi \\
\hline $\begin{array}{l}\text { e. Dengan menggunakan SIK pemrosesan data dapat } \\
\text { cepat }\end{array}$ & 9 & 29 & 36,2/Tinggi \\
\hline \multicolumn{4}{|l|}{ Minat untuk Menggunakan SIK } \\
\hline $\begin{array}{l}\text { a. Saya akan menerima penerapan SIK apabila } \\
\text { diterapkan }\end{array}$ & 5 & 33 & 37/Tinggi \\
\hline $\begin{array}{l}\text { b. Saya bersedia bertanya apabila ada kesulitan dalam } \\
\text { menggunakan SIK }\end{array}$ & 10 & 28 & 36/Tinggi \\
\hline $\begin{array}{l}\text { c. Saya bersedia mengikuti sosialisasi/pelatihan tentang } \\
\text { SIK }\end{array}$ & 15 & 23 & 35/Tinggi \\
\hline $\begin{array}{l}\text { d. Saya akan menyarankan bidan yang lain untuk } \\
\text { menggunakan SIK }\end{array}$ & 14 & 24 & 35,2/Tinggi \\
\hline $\begin{array}{l}\text { e. Saya berencana menggunakan SIK untuk penyelesaian } \\
\text { pencatatan dan pelaporan }\end{array}$ & 4 & 34 & 37,2/Tinggi \\
\hline $\begin{array}{l}\text { Hasil pengujian yang telah dilakukan, } \\
\text { diperoleh nilai t sebesar } 4,275 \text { dengan } \\
\text { signifikansi } 0,000 \text { yang berarti jauh dibawah } \\
0,05 \text { maka dapat disimpulkan bahwa H0 } \\
\text { ditolak dan H1 diterima yang berarti bahwa } \\
\text { terdapat pengaruh persepsi terhadap } \\
\text { kemudahan dengan sikap untuk } \\
\text { menggunakan sistem informasi pelayanan }\end{array}$ & \multicolumn{3}{|c|}{$\begin{array}{l}\text { kesehatan ibu di Dinas Kesehatan } \\
\text { Kabupaten Bungo. } \\
\text { Menu-menu yang disediakan pada } \\
\text { sistem informasi pelayanan kesehatan ibu di } \\
\text { Dinas Kesehatan Kabupaten Bungo mudah } \\
\text { dipahami oleh bidan karena format sub } \\
\text { menu pada menu Data Ibu Hamil hampir } \\
\text { sama dengan format kohort ibu hamil }\end{array}$} \\
\hline
\end{tabular}


sehingga bidan sudah familiar dan tidak rumit dalam memasukkan data pada Form Data Ibu Hamil. Hasil penelitian ini sesuai dengan hasil penelitian yang diperoleh Sami Binyamin, Malcolm Rutter dan Sally Smith di mana variabel Kemudahan berpengaruh terhadap sikap untuk menggunakan sistem informasi pelayanan kesehatan ibu. ${ }^{4}$

Hasil uji pengaruh persepsi kemudahan terhadap minat untuk menggunakan sistem informasi pelayanan kesehatanibudi Dinas Kesehatan Kabupaten Bungo menunjukkan nilai $\mathrm{t}$ sebesar 3,375 dengan signifikansi 0,002 yang berarti terdapat pengaruh signifikan. Bidan di Dinas Kesehatan Kabupaten Bungo memiliki kecenderungan perilaku untuk tetap menggunakan sistem informasi pelayanan kesehatan ibu, mereka beranggapan bahwa akan menerima penerapan sistem informasi pelayanan kesehatan ibu dan menyelesaikan pencatatan dan pelaporan menggunakan sistem tersebut.

Berdasarkan wawancara dengan responden, sistem informasi pelayanan kesehatan ibu sangat mudah untuk diakses, sehingga responden beranggapan untuk menerapkan sistem informasi pelayanan kesehatanibu di Dinas Kesehatan Kabupaten Bungo.

Hasil penelitian ini sesuai dengan hasil penelitian yang diperoleh Panayiotis Ketikidis, Lambros Lazuras, Tomi Dimitrovski dan Peter A Bathdi mana variabel Kemudahan berpengaruh terhadap minat untuk menggunakan sistem informasi pelayanan kesehatan ibu. ${ }^{5}$

Dari hasil pengujian yang telah dilakukan, diperoleh nilai $t$ sebesar 3,167 dengan signifikansi 0,003. Hal ini menunjukkan bahwa terdapat pengaruh signifikan pada persepsi terhadap kemanfaatan terhadap sikap untuk menggunakan sistem informasi pelayanan kesehatan ibudi Dinas Kesehatan Kabupaten Bungo.
Bidan di Dinas Kesehatan Kabupaten Bungo memiliki anggapan bahwa penggunaan sistem informasi pelayanan kesehatan ibu akan meningkatkan keterampilan dalam pencatatan dan pelaporan sehingga bidan beranggapan untuk menerima penggunaan sistem informasi pelayanan kesehatan ibu. Berdasarkan wawancara dengan responden, sistem informasi pelayanan kesehatan ibu dapat meningkatkan kemampuan untuk menyelesaikan pencatatan dan pelaporan, sehingga responden beranggapan penyelesaian laporan dapat dengan cepat terselesaikan.

Hasil penelitian ini sesuai dengan hasil penelitian yang diperoleh Craig Gambledi mana variabel Kemanfaatan berpengaruh terhadap sikap untuk menggunakan sistem informasi pelayanan kesehatan ibu. ${ }^{6}$

Terdapat hubungan signifikan antara persepsi terhadap kemanfaatanterhadap minatuntuk menggunakan sistem informasi pelayanan kesehatan ibu di Dinas Kesehatan Kabupaten Bungo dengan nilai $t$ sebesar 3,916 dengan signifikansi 0,000. Bidan di Dinas Kesehatan Kabupaten Bungo memiliki kecenderungan perilaku untuk tetap menggunakan sistem informasi pelayanan kesehatan ibu, mereka beranggapan bahwa akan menerima penerapan sistem informasi pelayanan kesehatan ibu dan menyelesaikan pencatatan dan pelaporan menggunakan sistem tersebut.

Berdasarkan wawancara dengan responden, sistem informasi pelayanan kesehatan ibu dapat meningkatkan kemampuan untuk menyelesaikan pencatatan dan pelaporan, sehingga penyelesaian laporan dapat dengan cepat terselesaikan.

Hasil penelitian ini sesuai dengan hasil penelitian yang diperoleh Stavros Nikou, Anastasios Economides di mana variabel Kemanfaatan berpengaruh terhadap 
minat untuk menggunakan sistem informasi pelayanan kesehatan ibu. ${ }^{7}$

\section{KESIMPULAN}

Pada penelitian ini dapat disimpulkan bahwa variabel persepsi terhadap kemudahan berpengaruh secara signifikan terhadap sikap $(p$-value $=0,000)$ dan minat $(\mathrm{p}$-value $=0,002)$ untuk menggunakan sistem informasi pelayanan ibu. Selain itu, variabel persepsi terhadap kemanfaatan juga menunjukkan pengaruh yang signifikan terhadap sikap $(p$-value $=0,003)$ dan minat $(p$-value $=0,000)$ untuk menggunakan sistem informasi pelayanan ibu.

\section{DAFTAR PUSTAKA}

1. Kementrian Kesehatan RI. Pedoman Pemantauan Wilayah Setempat Kesehatan Ibu danAnak (PWS-KIA). Kemenkes RI; Jakarta; 2010

2. Panagiotis K, Tomislav D, Peter B and Lambros L. Revised Technology Acceptance Model in Health Professionals: An Application of the Acceptance of Health Information Technology. Health Informatics Journal. Jun 2012; Vol 18 No 2; 124-34

3. Hartono, J. Sistem Tatakelola Teknologi Informasi. Andi; 2011

4. Sami B, Malcolm JR and Sally S. The Students Acceptance of Learning Management Systems in Saudi Arabia: A Case Study of King Abdulaziz University. International Technology, Education and Development Conference. 2017; 9324-9333

5. Panayiotis K, Lambros L, Tomi D and Peter AB. Acceptance of Health Information Technology in Health Professionals: An Application of The Revised Technology Acceptance Model. Health Informatics Journal. June 2012; vol 18 ; no. 2 ; $124-34$

6. Craig G. Exploring EFL University Students Acceptance of E-learning
Using TAM. Kwansei Gakuin University Humanities Review. May 2017; vol 22; 23-37

7. Stavros N and Anastasios E. MobileBased Assessment: Investigating The Factors That Influence Behavioral Intention To Use. Computers \& Education. Feb 2017; vol 109; 56-73 